\title{
GCU
}

Glasgow Caledonian

University

University for the Common Good

\section{Governance: public governance to social innovation?}

Massey, Andrew; Johnston-Miller, Karen

Published in:

Policy and Politics

DOI:

10.1332/030557314X14042230109592

Publication date:

2016

Document Version

Author accepted manuscript

Link to publication in ResearchOnline

Citation for published version (Harvard):

Massey, A \& Johnston-Miller, K 2016, 'Governance: public governance to social innovation?', Policy and Politics, vol. 44, no. 4, pp. 663-675. https://doi.org/10.1332/030557314X14042230109592

\section{General rights}

Copyright and moral rights for the publications made accessible in the public portal are retained by the authors and/or other copyright owners and it is a condition of accessing publications that users recognise and abide by the legal requirements associated with these rights.

Take down policy

If you believe that this document breaches copyright please view our takedown policy at https://edshare.gcu.ac.uk/id/eprint/5179 for details of how to contact us. 


\section{Governance: Public Governance To Social Innovation?}

\section{Introduction}

Within this period of financial austerity governments have increasingly sought to reduce public expenditure and thereby the role of the state. Yet, they have to meet rising expectations for increased provision and quality of public services as well as address complex policy problems such as social exclusion. This has led to calls for innovative policy solutions (see Osborne and Brown, 2013). But this revisionist view of the state is not a new phenomenon as governments have followed neoliberalism in reform of the state over the past decades. The global adoption of New Public Management (NPM) reforms has been an attempt to improve the capacity of administrative systems to effectively and efficiently deliver upon policies and public services. There has to some extent been a convergence of NPM type reforms in European Union (EU) countries and elsewhere (Pollitt and Bouckaert, 2011; Torres, 2004). Many countries have moved from hierarchical modes of public service delivery to the integration of markets, the involvement of societal sectors in the delivery of public services and the development of new modes of service delivery. The EU provided a context for the diffusion of NPM and neoliberal reforms of the state (see Ehrler, 2012). This was achieved through a process of policy transfer, isomorphism and regulation; continuing on the neoliberal trajectory of reforming the state (Radaelli, 2000; Radaelli and De Francesco, 2007; Bulmer et al, 2007). The European Commission (EC) has recently embraced the idea of social innovation, investing research and development resources to encourage member states to innovate public policies and service delivery in order to address complex socioeconomic challenges. This article explores the idea of social innovation and argues that it is not a 'new' mode of governance, but as a continuum of the neoliberal, reductionist view of the role of the state.

\section{Governance and Public Governance}

The literature on the delivery of public services through various policy and societal actors has been conceptualised as 'governance', in reference to the changing nature of the policy process and service delivery over recent decades. The term is often used in conjunction with the diversity of domains (e.g. supranational, national and sub-national) and actors (e.g. from the political, public, private, civil society and community realms) involved in the policy process (Richards and Smith, 2002; Rhodes, 1997; 2006). Governance is often used within the context of replacing government as a hierarchical mode of service delivery as part of the public services reform movement (NPM and reinventing government) toward the integration of and public service delivery through non-state actors such as private and civil society sectors (see Fairholm, 2010). Klijn (2012) provides a conceptual comparison of NPM vis-àvis governance as illustrated in Table 1 .

\section{[insert Table 1 here]}

Rhodes' characterises governance as interactions between actors within governing networks (Rhodes, 2000). Rhodes (2000; 2011) defined governance as self-organising, interorganisational networks. He argues that governance involves interdependence between organisations with governance being broader than government covering non-state actors (Rhodes, op cit). Governance therefore refers to changing the boundaries of the state between public, private and voluntary sectors with continuing interactions between network members 
with an exchange of resources and a negotiated shared purpose (Rhodes, op cit). These interactions are game-like, rooted in trust and regulated by rules of the game negotiated and agreed by network participants. Furthermore, there is a significant degree of autonomy with networks not accountable to the state, but self-organising with the state 'steering' them (Rhodes, op cit).

Key to the concept of governance is networks which have resulted in new forms of structural relationships, interdependencies and dynamics between actors for the mobilisation of resources between actors where resources are widely dispersed (see Kooiman, 1993). Thus, governance is a much broader term than government with public resources and services provided by any permutation of government, private and civil society organisations (Rhodes, 2006; Pierre and Peters, 2000). Public governance could be understood within the concept of governance as state and non-state actors in networks acting collectively to achieve public policy objectives. Bovaird and Löffler (2003: 316) describe public governance as '...the ways in which stakeholders interact with each other in order to influence the outcomes of public policies.' Skeltcher et al (2005) characterise public governance as institutional arrangements in some form of 'partnership' through which government, private, voluntary and community sector actors engage in a process of debating, deliberating and delivering public policy. Kooiman (2003) describes public governance as four modes of governance: communicative governance with engagement or exchange of information between state and non-state actors; public-private partnerships; co-management of public services; and networks.

The literature on governance is vast and a review by Klijn and Koppenjan (2012) for this journal has already been undertaken. We therefore summarize the general consensus that governance involves:

1. A set of institutions and actors that are drawn upon beyond the boundaries of government;

2. A blurring of boundaries and responsibilities for tackling socio-economic issues;

3. A power dependence involved in the relationships between institutions involved in collective action;

4. Autonomous self-governing networks of actors; and

5. The capacity to achieve policy objectives which do not necessarily depend on government to command or use its authority (Stoker, 1998; Bevir, 2009; Koliba, Meek and Zia, 2010; Levi-Faur, 2012).

We turn our attention to social innovation as a concept increasingly appearing in EC and member countries' policy agendas. As the title of this paper indicates we question (indeed, we seriously doubt) whether social innovation is a new mode of governance rather than a continuum representing the relationship between the state, market and civil society along a neoliberal trajectory. We suggest that often the term social innovation is simple rhetoric deployed by EU politicians, signifying little that is substantive.

\section{Social Innovation: a new mode of governance?}

José Barroso, President of the EC, at a social innovation conference in Brussels on 18 November 2011, expressed a commitment to social innovation stating that it would be mainstreamed in EC policy such as the Horizon 2020 strategic framework for research and innovation. These efforts would be complemented by the European Research Council research funding and EC investments such as a $€ 90$ million financial instrument to provide 
social investment funds and financial intermediaries with equity, debt and risk-sharing instruments; a new investment priority for social enterprises to allow member states to include targeted measures in their programmes under the cohesion funds from 2014 onwards; and the establishment of a single on-line data and exchange platform at European level to help professionals in the social business and innovation sector in their daily work (Barroso, 2011). The EC views social innovation and social business as the key to more a sustainable, responsible and inclusive Europe (ibid). Even member countries have begun to support social innovation activities. For example in March 2012 the Italian government launched a $€ 40$ million fund for social innovation projects (see http://www.ponrec.it/media/109513/84_ric_2mar12_avviso_smart_cities.pdf). Similarly, in the United Kingdom, the government in April 2012 launched the Big Society Capital Fund of $£ 600$ million to develop socially orientated investment organisations that support charities and social enterprises which are socially innovative with the aim of achieving a social impact (see http://www.number10.gov.uk/news/prime-minsiter-unveils-big-society-capital/). The EU Framework Programme for Research and Innovation for 2014 to 2020 with an estimated $€ 80$ billion budget will focus on the theme of social innovation and with a $€ 31748$ million budget dedicated to social innovation in addressing policy problems such as social exclusion (see http://ec.europa.eu/research/horizon2020/index_en.cfm?pg=h2020).

Whilst remaining a nebulous, amorphous catch-all concept, the term social innovation is gaining salience in EU policy documents with a significant amount of financial investment to support projects and other activities in the area. There have been some attempts to pin it down definitively and descriptively, mainly through listing its traits. Conceptually, social innovation is often described as the process of invention, diffusion and adoption of new services or organisational models, whether in the voluntary, public or private sector (EU and Young Foundation 2010). Proponents argue that social innovation transcends sectors to discover processes that produce sustainable impact which produce solutions to social problems (ibid). Phills, Deiglmeier and Miller (2008) define social innovation as a novel solution to a social problem that is more efficient, effective and sustainable than existing solutions and for which value created accrues primarily to society as a whole, rather than private individuals. It is argued that social innovation seeks to: (1) identify and deliver new services that improve the quality of life of individuals and communities; and (2) identify and implement new labour market integration processes, new competencies, new jobs, and new forms of participation, as diverse elements that each contribute to improving the position of individuals in the workforce (EU and Young Foundation 2010). Thus, social innovation is concerned with improving the quality of life and welfare of individuals and communities which is achieved through employment, consumption and/or participation with the expressed purpose of being able to provide solutions for individual and community problems (ibid).

Mulgan, Tucker, Ali and Sanders (2007:8) describes social innovation as '...activities and services that are motivated by the goal of meeting a social need and that are predominantly developed and diffused through organisations whose primary purposes are social'. Mulgan et al (2007) go onto describe stages of social innovation which enables new ideas to flourish and ensure the sustainability of the solutions for social needs:

1. Generating new ideas by understanding needs and identifying potential solutions. The starting point for innovation is an awareness of a need that is not being met and some idea of how it could be met; 
2. Developing, prototyping and piloting ideas. This stage involves taking a promising idea and testing it out in practice as few ideas survive an encounter with reality, but the idea may evolve and improve;

3. Assessing then scaling-up and diffusing the good ideas. Social innovation process involves an idea that is proven in practice and can grow, organically, be replicated, adopted and franchised. Innovations follow an ' $\mathrm{S}$ curve' in adoption with the early phase slow in growth amongst a small group of supporters, then rapid take-off and then slowing down as saturation and maturity is achieved;

4. Learning and evolving is the final stage of social innovation when the adaptation of ideas develops into new forms which may be very different from the expectations of the pioneers. Thus social innovation ideas evolve by becoming formalised as best practices are developed and the organisation learns how to make the idea work.

Murray, Caulier-Grace and Mulgan (2010) developed a model of the process of social innovation (see Figure 1). As the stages describe, the goal of social innovation is systemic change to achieve a social goal and create value beyond existing processes. It is argued in public policy terms this is significant because traditional, hierarchical modes of governance in addressing policy problems such as poverty and social exclusion are proving ineffective. Thus the issue is not merely to develop a new idea, but ensure that it is workable in practice that presents good practice, is sustainable and once scaled-up into public policy processes leads to systemic change.

[insert Figure 1 here]

A report by Hubert (2010), as an advisor in the Bureau of European Policy Advisors, defined social innovation as '...new ideas (products, services and models) that simultaneously meet social needs (more effectively than alternatives) and create new social relationships or collaborations. In other words they are innovations that are not only good for society but also enhance society's capacity to act.' Hubert (2010) identifies barriers to social innovation such as financing, governance and coordination, legal and cultural recognition, skills and training, and the lack of data and measurement. She goes on to state that the knowledge of social innovation is scarce and fragmented and contributes to the difficulty in providing social innovation amongst policy makers with an evidence base of what works (ibid).

The literature on social innovation demonstrates that public, private and/or voluntary sectors can form partnerships and networks to co-produce innovative practices which have an outcome of improving socio-development. This is not a new. The preceding discussion of governance captures social innovation. Sørensen and Torfing (2013) argue that social innovation is a shift from NPM and governance with more opportunities for collaboration but acknowledge that there are significant barriers to innovation. They note that political and institutional barriers to collaboration which would enable innovation (ibid). Indeed in a report by the OECD (2010) on social innovation outlined how government should play a steering role by improving mechanisms to foster networks for innovation; creating platforms for innovation; and developing frameworks for measuring the broader, more networked concept of social innovation and its impacts to guide policy making. Thus based on this conceptual discussion we argue that social innovation borrows much from NPM and neoliberalism by integrating civil society and the market through networks to deliver services and address policy problems.

\section{Social Innovation: A Critical Perspective}


The research on social innovation reveals that it is a nebulous concept which often lacks a theoretical foundation of the effectiveness and efficacy of social innovation in addressing policy problems. Mulgan (2011) for example wrote that there is a need to develop theoretical foundations in social innovation. He recognised gaps in social innovation theory given its broad dimensions and interpretation (ibid). He also argues that social innovation is shaped by historical circumstances such as prevailing types of institutions; usually develops from tensions with the challenge to understand and capture these tensions; has an underlying ethic of collaborations which can be technocratic and top-down; and there is evidence to suggest that the transferability of social innovation is difficult i.e. what works in one place does not necessarily imply that the same model would apply in another place or context (ibid). Moreover, Mulgan (2011) states that social innovation is not a fully defined domain and in order to provide the 'glue' to hold social innovation practice together, common measures of success need to be identified.

Similarly, Adams and Hess (2010) in their review of social innovation in practice and policy significance observed that although there are areas of social innovation, theoretical commentary which could lead to the development of models in practice and the sustainability of social innovation is less evident. Moreover, Adams and Hess (2010) call for the identification of characteristics of social innovation which could be integrated into organisational responses to create social value. They argue that there is a need to shift from top-down, expert knowledge and technocratic positivist approaches to local action in which approaches to issues are constructed in the process of dealing with them (Adams and Hess 2010). Thus, they support the bottom-up ideation of social innovation. They describe social innovation as being driven by the need for social wellbeing; that the location of social innovation can be found in the community; the leadership of social innovation is distributed; ideas stem from networks; actions are inter-sectoral; relations are built on trust; interventions are facilitating network formation or capacity building; and governance arrangements are based on partnerships (see also Le Ber et al 2010).

Research by Taatila, Suomala, Siltala and Keskin (2006) similarly found that while we live in a network society where the combination of knowledge and creativity creates a favourable environment for innovation, there is a need to study innovation processes. They conclude that the reliability of theory in generation could be further improved by making innovation studies, such as they have undertaken in Finland, to other locations and other cultural settings (Taatila, Suomala, Siltala and Keskin 2006:323). Another study of social innovation by Bright and Godwin (2010) found that there are two approaches to social innovation: (1) the planned approach which fosters hierarchically driven innovation; and (2) the emergent approach which fosters bottom-up, self-organising innovation. Their research found that it is the emergent approach which empowers individuals across organisations and encourages initiative in the development of new ideas (ibid). A criticism of their research is that it relies on one case study organisation, World Vision, to illustrate their arguments and a similar criticism could be made of other research in this area: much of social innovation research tends to be of descriptive case studies, often focused at an organisational level and/or a country specific location or cultural setting, lacking in comparative analysis to allow for external validity of an evidence base of what works in advancing socio-development.

Pol and Ville (2009) criticise academic scholarship of social innovation arguing that definitions of social innovation are vague and lacking in clarity, making it therefore difficult to conduct analysis without a conceptual framework. They argue that semantic clarification is 
necessary for both interdisciplinary communication and empirical inquiry of social innovation (ibid). Pol and Ville (2009) provide a model of the relationship between social innovation and business innovation and claim that to encourage the creation of pure social innovation, that is innovation located in the interface between social and business innovation, government intervention is necessary. Despite the Pol and Ville's (2009) criticisms of other scholarship of social innovation, they too do not clarify the factors which would enable social innovation to become sustainable and produce systemic change. Indeed Pol and Ville (2009:878) state that some scholars consider social innovation as 'no more than a buzz word or passing fad that is too imprecise to be usefully applied to academic scholarship.'

Despite these criticisms social innovation is increasingly being viewed as solution to socioeconomic policy problems within this period of austerity. Yet, the research reveals that social innovation is conceptually difficult to define, lacking in theoretical grounding and indeed the evidence base of the effectiveness of social innovation in addressing socio-economic challenges is lacking.

\section{Public Governance to Social Innovation: Old Wine in New Bottles?}

Social innovation is a politically useful label acquiring talismanic top-down quality to signify attempts to address the pressing social problems besetting the EU. The idea of what is 'new' arguably is socially constructed as what is considered a 'new' mode of service delivery in one organisation, sector or context may not be 'new' to another. Indeed, 'new' ways of delivery services can become embedded through isomorphic and heuristic approaches intra-and-interorganisationally with time being a factor. For example, technologies developed and employed by a private sector organisation may at the time be considered as new and innovative, and then may be adopted by a public sector organisation. Within this context what is new and innovative for the public sector organisation is not for the private organisation. Social innovation is therefore contingent on context and the meaning of what is 'new'. Thus, the social construction of social innovation depends on whether the network of actors or organisation considers the mode of service delivery as a departure from previous, extant practice and constructs meaning around what it considers as 'new' (see Bevir, 2009 on social constructivism and governance).

Social innovation and public governance share common characteristics as it involves state and non-state actors collaborating in networks to achieve socio-economic policy outcomes. Is social innovation old wine in new bottles or is social innovation a new mode of governance? Social innovation we argue is part of a neoliberal agenda of minimalist state intervention by encouraging non-state actors to achieve socio-economic policy outcomes. Perhaps this is where the convergence of concepts ends, that is the role of non-state actors in public governance networks to achieve policy outcomes. Yet, there is a divergence: an analysis of social innovation projects (see websites of the Young Foundation, Social Innovation Exchange, Social Innovation Europe, and the Centres for Social Innovation in Canada and Austria) reveals that the process is more 'bottom-up' than the top-down, hierarchical mode of governance. Goldsmith (2010) argues that social innovation is civic solutions developed from the ground up. Indeed the Harvard Kennedy School of Government's project on social innovation is entitled 'building solutions from the ground up' (see http://socialinnovation.ash.harvard.edu/). This bottom-up process is often in response to the neoliberalism and the retraction of the state. While the NPM mantra was 'doing more with less', in the era of austerity it appears the new doctrine is, 'you do more and we do less' with a reduction in public services and a shift of service provision onto societal sectors. The 
retraction of the state has resulted in some communities forming civic, grassroots networks to address the lack of welfare and service provision. Social innovation we argue is therefore not a mode of governance. Governance involves the state as an authoritative sector steering through various networks through regulatory frameworks. Social innovation is communitarian, voluntary activism which is localised at the 'bottom', grassroots micro level. It is difficult to scale-up or diffuse these bottom-up initiatives to achieve broader societal and policy objectives because the transferability is beyond the capacity of community and social innovation actors. For example, an EC funded research project, WILCO, on welfare innovations in 20 cities across Europe found that innovative ideas are restricted by the locally prevailing general discourses and although there may be support from officials and experts in a special policy field, the localism of the innovation limits its transferability to other contexts (see http://www.wilcoproject.eu/innovations-in-20-european-cities-new-city-reports/). The WILCO project acknowledges that there are many context factors that have an impact on innovations but of central importance is the value orientations of the local political administrative system to ensure social innovation is scaled-up. Similarly, another EC funded research project, TEPSIE (see http://www.tepsie.eu/), found barriers to social innovation. We summarise these as follows:

- 'Psychology and social traps' within communities such as being caught in a vicious cycle of poverty which present cognitive and capability limitations in being innovative;

- Barriers to market entry which may explain why it can be difficult to set up socially innovative activities;

- Insufficient growth mechanisms such as economies of scale, learning by practice and capital in order to scale-up social innovation process;

- Insufficient leveraging mechanisms such as leadership required to develop networks, partnerships and other mechanisms for leveraging social innovations from small scale projects to large scale programmes;

- The collective nature of the goods and services delivered by social innovation raises specific challenges for social innovators such as the need to organise some form of collective action, funding, engagement with government, and consequently the impossibility of the continued community or private appropriation of social innovation;

- The collective nature of the goods and services delivered by social innovation often implies that public organisations play an important role in triggering, supporting and scaling up the innovation, but these are organisations often require regulatory adherence which may harm the innovation process; and

- Social innovation is also about social innovators being capable of motivating others to participate in new ways to respond to social needs, but they fail to do so because od insufficient financial and other resources needed to accomplish goals, they may not be capable of improving outcomes for their target populations, and/or they may not be able to prevent the process from being captured by others (Mendes et al, 2012).

Thus, when social innovation actors engage with state actors in networks principally to secure financial resourcing to scale-up projects, there is consequent adherence to public sector accountability, regulatory, professional and performance measures. When the process and practice of addressing a socio-economic challenge is grassroots, civic based it remains an innovation social in nature at the 'bottom', but when it moves towards the trajectory from the 'bottom-up', scaling-up to affect systemic change it necessitates interaction with state actors in government as the authoritative sector. It then enters the realm of public governance. Thus, 
in order to move from a micro level, grassroots civic activity to a broader macro, scaled-up process it requires larger scale investment of resources, principally from the state given its public service functionality. Furthermore, regulatory authorisation is also required if the social innovation activity is scaled-up impacting upon society in general. The capacity to deliver services which address socio-economic challenges requires professional skills. The financial investment, regulatory approval and professional networks have consequent accountability requirements. Once social innovation actors extend the network seeking government support and interacting with state actors within professional networks, the innovative process becomes part of the public governance realm: state and non-state actors interacting in a network to deliver services and address policy problems.

There will always be service delivery which involves state actors and we would generally understand this within the realm of government with hierarchical mode of public service delivery residing within public organisations which have the authority to deliver services derived from a rational-legal, constitutional basis. Increasingly, services are being delivered with the involvement of non-state actors as part of public governance. The scope to deliver services within a public governance context depends on capacity (e.g. professional expertise, organisational skills), resources (e.g. time, financial), leadership and commitment to undertake the challenge of addressing a socio-economic problem. We will see in the future more and more public services being delivered though public governance arrangements. Arguably, whether conceptualised as public governance or social innovation, it is an extension of neoliberal reforms of the public sector and questions remain whether this leads to improvements in public services. However as an EC (2013) commissioned report observed, social innovation remains at the micro, at best, meso level rather than at the societal level.

\section{Conclusion}

This paper has examined the concepts of governance, public governance and social innovation. The conceptual framework of governance, particularly public governance was juxtaposed with that of social innovation. There are a number of issues to consider: the power dynamics between state and non-state actors in networks; the accountability of non-state actors in the public governance of public services; and the professional capacity of actors. Further research on social innovation is necessary to understand the process and interaction between state and non-state actors, whether it is effective and factors which contribute to social innovation failures (see Brandsen, 2013). Nonetheless we argue that social innovation has gained traction on the public policy agenda because it is a palatable term justifying continued neoliberal reforms of the state within this period of financial crisis and austerity measures. It is obfuscates political objectives of reducing social transfers and public services by encouraging communities to be innovative in solving their own problems and being selfsufficient. Arguably, this may empower communities, but minimalist state intervention and reduction in social welfare services and transfers often disempowers communities. Without state support to address structural barriers (as outlined above), socio-economic disparities continue. The move of social innovation onto the public policy agenda may in fact see its trajectory increasingly becoming that of public governance as a mode of public service delivery. Indeed it could be argued that social innovation once adopted, supported and scaledup within the public policy process could cease to be conceptualised as social innovation but that of public governance. The EU has always attempted to capture networks to achieve policy outcomes through financial and regulatory instruments. We conclude that social innovation is not a mode of governance but it is how government seeks to govern better 
through a network of societal actors. We argue that social innovation is a continuum of neoliberalism with the state encouraging non-state or community activism, shifting service provision onto societal sectors and steering with minimal state investment.

\section{References}

Adams, D and Hess, M. (2010) 'Social Innovation and why it has Policy Significance', The Economic and Labour Relations Review, 21 (2): 139-156.

Barroso, J.M.D. (2011) 'Building responsible and sustainable growth - the role of social entrepreneurs', available at http://europa.eu/rapid/press-release_SPEECH-11775_en.htm?locale=en, accessed June 2013.

Bevir, M. (2009) Key Concepts in Governance, London: Sage Publishing.

Blumer, S., Dolowitz, D., Humphreys, P. and Padgett, S. (2007) Policy Transfer in the European Union Governance: regulating the utilities, Routledge: Oxon.

Bovaird, T. and Löffler, E. (2003) 'Evaluating the Quality of Public Governance: Indicators, Models and Methodologies', International Review of Administrative Sciences, 69 (3): 313328.

Brandsen, T. (2013) 'The WILCO Project: study social innovation at local level', http://www.slideshare.net/SocialFrontiers/brandsen-151113-presentation, accessed February 2014.

Bright, D.S. and Godwin, L.N. (2010) 'Encouraging Social Innovation in Global Organizations: integrating planned and emergent approaches', Journal of Asia-Pacific Business, 11: 179-196.

Ehrler, F. (2012) 'New Public Governance and Activation', International Journal of Sociology and Social Policy, 32 (5/6): 327-339.

European Commission (2013) Social Innovation Research in the European Union, http://ec.europa.eu/research/social-sciences/pdf/social_innovation.pdf, accessed February 2014.

European Union and The Young Foundation (2010) Study of Social Innovation, A paper presented by the Social Innovation Exchange (SIX) and the Young Foundation for the Bureau of European Policy Advisors, London: Young Foundation.

Fairholm, M.R. (2010) 'Why a rational move towards "Governance" may destroy the soul of Public Administration: Or why Governance Isn't Concerned with Government Anymore', in T. Brandsen and M. Holzer (eds.) The Future of Governance, Newark: National Centre for Public Performance, EGPA/IIAS and American Society for Public Administration.

Goldsmith, S. (2010) The Power of Social Innovation, San Francisco: Jossey-Bass.

Hubert, A. (2010) Empowering People, Driving Change: Social Innovation in the European Union, Luxembourg: Publications Office of the European Union.

Klijn, E. (2012) 'New Public Management and Governance: a comparison' in D. Levi-Faur (ed.) The Oxford Handbook of Governance. Oxford: Oxford University Press: 201-214.

Klijn, E.H. and Koppenjan, J. (2012) 'Governance network theory: past, present and future', Policy and Politics, 40 (4): 587-606

Koliba, C., Meek, J. and Zia, A. (2010) 'Gordian Knot or Integrated Theory? Critical Conceptual Considerations for Governance Network Analysis' in T. Brandsen and M. Holzer (eds.) The Future of Governance, Newark: National Centre for Public Performance, EGPA/IIAS and American Society for Public Administration.

Kooiman, J. (1993) Modern Governance: New Government-Society Interactions. London: Sage Publications.

Kooiman, J. (2003) Governing as Governance. London: Sage Publishing. 
Le Ber, M.J. and Branzei, O. (2010) '(Re)Forming Strategic Cross-Sector Partnerships: Relational Processes of Social Innovation', Business and Society, 49 (1): 140-172.

Levi-Fau, D. (ed.) (2012) Oxford Handbook of Governance, Oxford: Oxford University Press.

Mendes, A.M.S.C., Batista, A., Fernandes, L., Macedo, P., Pinto, F., Luís, R., Ribeiro, M., Ribeiro, R., Sottomayor, M., Tavares, M, and Verdelho, V. (2012) Barriers to Social Innovation,

http://www.tepsie.eu/images/documents/tepsie.d3.1barrierstosocialinnovation.pdf, accessed February 2014.

Mulgan, G. with Tucker, S., Ali, R. and Sanders, B. (2007) Social Innovation: What is it, why it matters and how it can be accelerated, London: The Young Foundation.

Mulgan, G. (2011) 'Social Innovation Theory - ideas for an emerging field', unpublished paper.

Murray, R., Caulier-Grice, Mulgan, G. (2010) The Open Book of Social Innovation, London: The Young Foundation.

OECD (2010) The OECD Innovation Strategy: Getting a Head Start on Tomorrow, OECD.

Osborne, S. and Brown, L. (eds.) (2013) Handbook of Innovation in Public Services, Cheltenham, Edward Elgar.

Phills Jr., J. A., Deiglmeier, K. and Miller, D.T. (2008) 'Rediscovering Social Innovation', Stanford Social Innovation Review, 6 (4): 34-43.

Pierre, J. and Peters, B.G. (2000) Governance, Politics and the State, Basingstoke: Macmillan.

Pol, E. and Ville, S. (2009) 'Social Innovation: buzz word or enduring term?', The Journal of Socio-Economics, 38: 878-885.

Pollitt, C and Bouckaert, G. (2011) Public Management Reform: a comparative analysis, Oxford: Oxford University Press.

Puchala, D. (1972) 'Of blind men, elephants and international integration', Journal of Common Market Studies, 10: 267-84

Radaelli, C. (2000) 'Policy Transfer in the European Union: Institutional Isomorphism as a Source of Legitimacy', Governance, 13 (1): 25-43.

Radaelli, C. and De Francesco, F. (2007) Regulatory Quality in Europe: Concepts, Measures and Policy Processes, Manchester, Manchester University Press.

Rhodes, R.A.W. (2011) 'The Governance Narrative: key findings and lessons from the ESRC's Whitehall Programme' in R.A.W. Rhodes (ed.) Public Administration: 25 years of analysis and debate, Chichester: Wiley-Blackwell.

Rhodes, R.A.W. (2006) 'The New Governance: Governing Without Government', Political Studies, 44 (3): 652-667.

Rhodes, R.A.W. (2000) 'Governance in Public Administration' in J. Pierre (ed.) Debating Governance: Authority, Steering and Democracy, Oxford: Oxford University Press.

Rhodes, R.A.W. (1997) Understanding Governance: Policy Networks, Governance, Reflexivity and Accountability, Buckingham: Open University Press.

Richards, D. and Smith, M. (2002) Governance and Public Policy in the United Kingdom, Oxford: Oxford University Press.

Skeltcher, C., Mathur, N. and Smith, M. (2005) 'The Public Governance of Collaborative Spaces: Discourse, Design and Democracy', Public Administration, 83 (3): 573-596.

Sørensen, E. and Torfing, J. (2013) Enhancing Social Innovation by Rethinking Collaboration, Leadership and Public Governance, http://rudar.ruc.dk//bitstream/1800/13187/1/191799289_Enhancing_Social_Innovation_by _Rethinking_Collaboration_Leadership_and_Public_Governance.pdf, accessed February 2014. 
Stoker, G. (1998) 'Governance as a Theory: five propositions', International Social Science Journal, 50 (155): 17-28.

Taatila, V.P., Suomala, J. and Keskinen, R.S. (2006) 'Framework to study the social innovation networks', European Journal of Innovation Management, 9 (3): 312-326.

Torres, L. (2004) 'Trajectories in public administration reforms in European Continental countries', Australian Journal of Public Administration, 63 (3): 99-112. 
Figure 1: Social Innovation Process

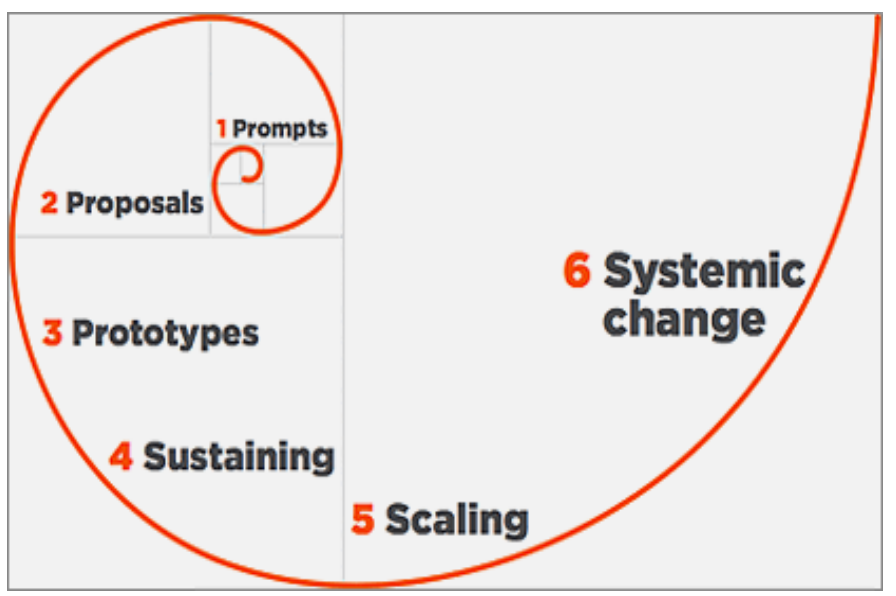

Sources: Mulgan et al (2007) 
Table 1: NPM and Governance

\begin{tabular}{|c|c|c|}
\hline & New Public Management & Governance \\
\hline Focus & $\begin{array}{l}\text { Organisational and } \\
\text { institutional changes and } \\
\text { adaptations within the public } \\
\text { sector (intra-organisational) }\end{array}$ & $\begin{array}{l}\text { Changes and adaptations in } \\
\text { the relations between } \\
\text { governments and other actors } \\
\text { (inter-organisational) }\end{array}$ \\
\hline Objectives & $\begin{array}{l}\text { Improving effectiveness and } \\
\text { efficiency of public service } \\
\text { delivery and public } \\
\text { organisations }\end{array}$ & $\begin{array}{lr}\text { Improving } & \text { inter- } \\
\text { organisational coordination } \\
\text { and quality of decision } \\
\text { making }\end{array}$ \\
\hline $\begin{array}{l}\text { Core ideas/management } \\
\text { techniques }\end{array}$ & $\begin{array}{l}\text { Using business instruments } \\
\text { (e.g. market mechanisms, } \\
\text { performance indicators) to } \\
\text { improve service delivery }\end{array}$ & $\begin{array}{l}\text { Using network management: } \\
\text { activating actors, organising } \\
\text { research gathering, arranging } \\
\text { interactions, etc. }\end{array}$ \\
\hline Politics & $\begin{array}{l}\text { Elected officials set goals } \\
\text { and implementation is } \\
\text { achieved by independent } \\
\text { agencies or market } \\
\text { mechanisms on the basis of } \\
\text { clear performance indicators }\end{array}$ & $\begin{array}{l}\text { Goals are developed during } \\
\text { interaction and decision } \\
\text { making processes, elected } \\
\text { officeholders are part of the } \\
\text { process or are meta- } \\
\text { governors }\end{array}$ \\
\hline Complexity & $\begin{array}{l}\text { Modern society is complex } \\
\text { but there is a need for clear } \\
\text { goals and flexible } \\
\text { implementation }\end{array}$ & $\begin{array}{l}\text { Modern society is complex } \\
\text { and requires interdependence } \\
\text { and interacting with actors in } \\
\text { society is unavoidable and/or } \\
\text { necessary to reach } \\
\text { satisfactory outcomes }\end{array}$ \\
\hline
\end{tabular}

Source: Klijn (2012) 
